\title{
Environmental Management Strategy In Schools: A Case Study At SMA Negeri 1 Bekasi, West Java
}

\author{
Marningot Tua Natalis Situmorang* \\ Department of Environmental Engineering, Faculty of Engineering, Universitas Sahid, Jakarta, Indonesia \\ uchoxs@yahoo.com \\ *Corresponding Author: uchoxs@yahoo.com | Phone : +6287849460456
}

Received: 11 August 2020

Revised: 13 September 2020

Accepted: 22 September 2020

\begin{abstract}
This paper aims to find out about school environmental management strategies in West Java secondary schools. To guide the study, three research questions were formulated. This is achieved by administering a structured questionnaire in a random sample school of 100 students. The findings show regular lawn cleaning, school complex sweeping and painting, landscaping and flower planting, good drainage and garbage disposal are strategies adopted for managing school environments. While the lack of gardeners to keep the school complex clean, erosion, students and teachers are not responsive to environmental problems, difficulties in instilling students' environmental values due to different care of homes, lack of funds for procurement of work tools/equipment and challenges of waste disposal are some of the challenges. Identified in the management of the school environment. For a better and better school environment for good academic practice, school environmental management team, plans for drainage and waste disposal, consideration of school locations for new schools, janitorial work, terminal orientation programs, development of curricula on environmental management, inspections and school competitions and awards are recommended.
\end{abstract}

Keywords: strategy; school environment; high school

\section{Introduction}

The challenges of environmental management today are very complex. To maintain a healthy and pleasant environmental quality, we need the right way to create a productive living environment. A productive environment will provide security to humans in managing their environment. One of the ways to maintain a comfortable environment is by disposing of all waste and trash to the place provided by the government, both organic and non-organic. Environmental management has become one of the greatest challenges facing the world today. These challenges include agents in the livestock sector, producers, decomposers and milk and milk producers, extension agents, technicians, NGOs, local and national governments, and the scientific community (Hernández-Castellano et al., 2019). So managing the environment for a fertile, healthy, and productive life is at the core of all human activities even though maintaining a healthy and healthy environment is always a challenge for humans. A healthy environment will prevent chronic diseases, which have been the main cause of death (Brown, Maslen, \& Savulescu, 2019). Besides that, the noise caused by motorized vehicles and hot air released from factories can also make the environment unpleasant and can damage human health. Various kinds of activities can be carried out to prevent environmental damage through comprehensive planning and coordination and plans to keep the environment fresh. Therefore environmental management is very much determined by the quality of humans. If the human quality is not good, then the environment will not be healthy and clean. And vice versa.

In this study, the concern is the school environment. Physically, the school environment is very important in supporting a healthy academic atmosphere for quality activities in the learning process. Therefore, to create a school atmosphere that can produce a learning process that is in line with expectations, ways are needed to develop and manage the environment. The location of the school can greatly determine the stability of students' minds for academic readiness. Emotional stability produces positive emotions (Miller, Ramirez, \& Murdock, 2017). Schools that are located along main roads, near roadsides (especially without fences), near industrial activities, markets, and so on will become a nuisance and distraction in student learning. This will produce enough noise to influence the learning process. This can affect the quality of the learning environment. This refers to all the strategies implemented by the school system in managing 
waste (noise, water and other wastes), drainage patterns, and facilities provided in schools. No less important is the greening of the school environment. Sanitation states that school management provides sanitation and planting of flowers, trees and lawn maintenance, well-cleaned grass, etc. Improve the quality of life and learning environment. The aesthetics of the school environment is another aspect of managing the school environment. The role of the principal in realizing and encouraging schools to be able to make it happen according to the school's vision (Lasno, Suriansyah, \& Saleh, 2019). Its implementation can be done through regular painting and maintaining the quality of the building, channelling waste, trimming flowers, cleaning the lawn, proper disposal of garbage, sweeping and removing children's nets, among others, providing a relaxed atmosphere for mind formation.

All of the above problems are a school environmental management strategy that can make the school a fun place to learn. In spite of these very important issues, very little has been done in managing the school environment for meaningful academic endeavours. A study of the strategies used in managing the school environment in high school Bekasi, West Java. How the school environment is managed aesthetically, recreation, solid waste, drainage patterns, and other physical views of the environment affect the quality of the children's learning environment. Therefore, this study is designed to investigate school environmental management strategies in West Java secondary schools; imagine that this research can provide and improve environmental management for SMA 1 Bekasi, West Java.

Based on the above problems, the research questions are detailed in three forms of questions, namely 1) what strategies exist in managing the school environment, 2) what problems are there between the management of the school environment and student learning habits, and 3) What is the management of the school environment? affect the quality of the school environment.

\section{Literature Review}

The physical environment of a school adds a lot of value to the school (Okoth, 2016). Rahmawati \& Armida (2019) believe that the physical environment contributes either negatively or positively to the performance of the administrator's role in schools. The physical environment of the school includes buildings, classrooms, furniture, equipment, teaching materials, laboratories, libraries, playgrounds, and so on (Ayers, 2013). Others are walls, machines, decorative objects, playgrounds, skating rinks, swimming pools, audiovisual equipment). In an effort to expand the education business, educational planners are more interested in issues such as the number of schools, teachers, student infrastructures such as classrooms and school buildings. Little attention is paid to environmental quality. The design and structure of the school environment form the physical appearance of the school that can attract the attention of parents and friends of educational institutions in the initial assessment of the quality that occurs in school. All have an effect on perceptions and preferences for desired learning experiences by parents and students. The learning environment has been emphasized as an essential requirement for the smooth running of the teaching and learning process. This is because students' study habits are largely tied to it. According to Gros (2016), the learning environment has a major effect on the efficiency of learning time. He identified noise, distraction, lighting, temperature, tidiness, comfort, and equipment as having potential effects on study habits. This is supported by Ade, Nagaraj, \& Vallepalli (2020) who state that because schools are important to provide a clean learning environment and water sanitation in the school environment. In addition, schools provide an ideal environment to help children adopt good habits that will be useful for the rest of their lives. However, managing the school environment has been a major challenge over the years for governments, school principals, and administrators. The challenges start from location, beauty, waste materials, sanitation, greening, and so on. It is common to see the school environment as poorly maintained. They are often littered with paper trash, dusty classrooms, poor ventilation, and gardens to sit in during recess. A clean environment stimulates learning and intellectual development. Little attention has been paid to the quality of the learning environment, perhaps because educational planners and providers have not received sufficient information about the role of the environment in enhancing learning and intellectual development. A further review in the literature includes the conditions of the library for reading and writing which are often not preferred; flooded toilets and urinary systems, school management with a strong odour and can aggravate the learning process situation.

\section{Methods}

This study used a survey method to investigate strategies for school environmental management in high schools, Bekasi, West Java. The reason is that it uses a representative sample from which the findings are made with reference to the entire population. The research location was conducted at SMA Negeri 1 Bekasi, West Java. The number of the population sampled in this study was 100 students. Of the 100 questionnaires given to students, 2 were filled badly and so they were discarded. The data that is filled in and returned 
correctly is the primary data for analysis. The respondents of this research consisted of men and women. Simple random sampling technique was used to select 33 students each from the school. Descriptive statistics were used to describe the data collected from the field at the 0.05 significance level. Data is presented in the form of simple tables, charts, graphs and percentages. This is to make the findings clearer and more understandable.

\section{Results and Discussion}

Results

Table 1. Shows the various ways of managing the school environment.

\begin{tabular}{clcc}
\hline \multicolumn{1}{c}{ Strategies } & Number of respondents & Percentages (\%) \\
\hline 1 & Clean the lawn regularly, sweep the school compound and paint & 37 & 36.2 \\
\hline 2 & Good drainage and garbage disposal & 17 & 16.6 \\
\hline 3 & Flower planting & 20 & 19.6 \\
\hline 4 & Etc & 22 & 21.5 \\
\hline
\end{tabular}

Total responses of 36.2 per cent (1) said that the school environment was managed through regular grass clearing, sweeping the school complex and painting, 23 respondents representing 23.5 (4) stated another, 22 per cent. Others, as shown, include lessons, orientation and debate. (3) have a landscape and flower planting, while 19.6 per cent (2) think that good drainage and garbage disposal are strategies in the management of the school environment.

Table 2. Effect of school environmental management.

\begin{tabular}{clcc}
\hline \multicolumn{1}{c}{ Strategies } & Number of respondents & Percentages (\%) \\
\hline No. & \multicolumn{1}{c}{ Reading/studying habits } & 7 & 6.8 \\
\hline 2 & Student concentration & 18 & 17.6 \\
\hline 3 & Their reading/study habits & 22 & 21.5 \\
\hline 4 & Other & 51 & 49.9 \\
\hline
\end{tabular}

As revealed in Table 2, Figure 1 management of the school environment has no effect at all on reading/learning habits, around 17.6 per cent of respondents (3), 21.5 per cent said it had an effect on their reading/learning habits. (1), 7 responses represented 17.3 per cent of respondents found the management of the school environment affected their concentration in class during lessons (2), while 49.9 per cent represented others.

Table 3. Students, gardeners and school cleaners are involved in managing the school environment

\begin{tabular}{|c|c|c|c|}
\hline No. & Strategies & Number of respondents & Percentages $(\%)$ \\
\hline 1 & Students & 5 & 49 \\
\hline 2 & Gardener & 17 & 16.6 \\
\hline 3 & Janitor & 8 & 7,8 \\
\hline 4 & Other & 10 & 9.8 \\
\hline
\end{tabular}

However, as many as 49.0 percent of teachers from table 3 indicate that students, gardeners and school cleaners are involved in managing the school environment. 16.6 percent of respondents thought that only students and gardeners were involved, 7.8 percent indicated that only school gardeners and cleaners played a role, while 9.8 percent had a different opinion stating that teachers, students, parents of teachers School gardeners and cleaners all play a role in managing the school environment. As shown in Table 3, the challenges of managing the school environment have a serious impact on the quality of the school environment with a response of 49.0 (a) per cent, while 16.6 per cent (b) think that it has no serious impact. Within the school environment, 7.8 (c) per cent felt that challenges had no effect at all on the quality of the school environment, and 9.8 (d) per cent indicated others.

Discussion

Discussion In general, the findings revealed regular lawn cleaning, sweeping the schoolyard and painting as the main strategies for managing the school environment. Others include landscaping and flower planting, as well as good drainage and garbage disposal. The management of the school environment was identified as having an influence on the reading/learning habits of some students, while for some it had no effect as tabulated in Table 2. It is clear that this is not just the idea that when the management of the school environment is not good it will have a negative impact on the quality of the school environment. This is in accordance with the findings (Nurdin, 2017) that the management of the school environment can stimulate learning and intellectual development. Joint efforts should be made to check for challenges such as noise from disturbing moving vehicles during lessons, sanitation/water supply problems, soiled paper, wrapping, dust and litter that did not collect, snake bites, scorpion stings, and other insects. Previous studies such as Rahmawati \& Armida (2019) have shown that ensuring a good school environment improves performance 
and even the role of administrators, let alone students. This problem can paralyze the work of all academic activities in general so that it needs to be addressed. Therefore it becomes important that the management of the school environment becomes a concern because it will improve the learning outcomes of many students with performance consequences. Each education stakeholder must contribute their quota in providing a comfortable learning atmosphere for students in secondary schools. The challenges of managing the school environment have a significant effect on the quality of the school environment. It is clear that this is not just an assumption that the management of the school environment is neglected or ignored will ultimately have a negative impact on the quality of the school environment. Bad habits in school toilets and drains do not receive adequate attention in maintaining student health. Such challenges can eliminate rather than stimulate learning and intellectual development. A concerted effort should be made to check for challenges such as noise from disturbing moving vehicles during lessons, sanitation / clean water supply problems, soiled paper, wrapping, dust and trash.

\section{Conclusions}

From the findings of this study, the following conclusions can be drawn: because the school environment is good and clean, the teaching and learning process will be more effective and encourage healthy living in schools according to the expected needs. All students and teachers in the school environment should always keep the school environment clean and beautiful. Based on these findings, the authors recommend that schools should have a team to maintain the school environment that includes the principal or teacher representatives, school committee student representatives and cleaners to continue to supervise while ensuring that the school environment is well managed. In addition, in extracurricular activities, the management of the school environment for secondary schools in West Java must be developed and it must be made mandatory and schools must introduce an orientation program at the beginning of each semester. This will redirect the mindset of students to manage the learning environment.

\section{References}

Ade, AD, Nagaraj, K., \& Vallepalli, C. (2020). School Environment and Sanitation: A Comparative Study. Ayers, W. (2013). Talking About Race: Alleviating the Fear. Stylus Publishing, LLC.

Brown, RCH, Maslen, H., \& Savulescu, J. (2019). Against Moral Responsibility of Health: Prudential Responsibility and Health Promotion. Public Health Ethics, 12 (2), 114129. https://doi.org/10.1093/phe/phz006

Gros, B. (2016). The design of smart educational environments. Smart Learning Environments, 3 (1), 15.

Hernández-Castellano, LE, Nally, JE, Lindahl, J., Wanapat, M., Al Haidary, IA, Fangueiro, D.,... de Almeida, AM (2019). Dairy science and health in the tropics: challenges and opportunities for the next decades. https://doi.org/https:// doi.org/10.1007/s11250-019-01866-6

Lasno, L., Suriansyah, A., \& Saleh, M. (2019). School Principal's Role In The Implementation Of School-Based Management For Adiwiyata Program. European Journal of Education Studies.

Miller, AD, Ramirez, EM, \& Murdock, TB (2017). The influence of teachers' self-efficacy on perceptions: Perceived teacher competence and respect and student effort and achievement. Teaching and Teacher Education, 64 , 260-269.

Nurdin, D. (2017). Managerial Competency of School Heads In Developing School Climate And Teacher Satisfaction In Elementary School. Elementary School: Study of Educational Theory and Practice, 24 (1), 4556.

Okoth, TA (2016). Challenges of Implementing a Top-down Curriculum Innovation in English Language Teaching: Perspectives of Form III English Language Teachers in Kenya. Journal of Education and Practice, 7 (3), 169-177.

Rahmawati, RA, \& Armida, S. (2019). The Effect of Education Level and Office Physical Work Environment on Employee Performance in the Office of Spatial Planning and Settlement Infrastructure, West Sumatra Province. Journal of Ecogen, 2 (3), 513-523. 